\title{
Morphological Characterization of Digenetic Trematodes and Their Effect on Immune System of Clarius gariepinus
}

\author{
Mai Nashaat, Samar Kamel and Heba M. A. Abdelrazek
}

\begin{abstract}
Immune system plays a pivotal role in fish protection against infections or infestations such as digenetic trematodes. Identification of trematodes and their adverse effects as well as body reactions toward it is considered an essential step to face such problem. Current research aimed to identify digenetic trematodes in cat fish (Clarius gariepinus) with special reference to their immune responses against such parasite as well as biochemical alterations. A total number of $100 \mathrm{C}$.gariepinus were collected live from wild populations in Ismailia city, Egypt. From July to November 2018. Cyst count was performed. Blood total leukocytes count; some blood biochemical parameters as well as spleenosomatic mass were recorded. Also histopathological examinations to different organs were performed. Results showed high prevalence infection with encysted metacercariae after using digestion method to isolate cysts. Total Leukocytes count (TLC) was none significantly altered with eosinophilia in heavy infested fish as well as spleenosomatic mass which indicate to higher activity of the immune system of the infested fish. All histopathological sections show presence of encysted metacercaria which causing necrosis and degenerations. These results gave insights on the use of probable immunostimulants to counter act such parasites, an appropriate approach to such infestation could minimize the coast directed towards controlling such problem.
\end{abstract}

Keywords - Clarius gariepinus; Immune response; Digenetic trematodes; Histopathology.

\section{INTRODUCTION}

The relative high price of animal proteins created a great world demand towards fish, due to its cheap source of proteins and also contains many nutrients required to the human body [1]. Most seafood is high in protein; vitamins and other important minerals, while low in calories, cholesterol and sodium which are harmful to the human health; many types of seafood are good source of vitamins B6 and B12 and also contain two other B vitamins known as niacin and riboflavin. Fish contain special kinds of fatty acids called omega 3, which was believed to reduce a person's risk for heart diseases and other illnesses. Minerals provided by various types of seafood include iodine, calcium, copper, magnesium, potassium, phosphorus, selenium and zinc, so it is recommended that to eat fish and other seafood because it considered important

Mai Nashaat, Fish pathology Lab. Aquaculture Division, National Institute of Oceanography and Fisheries (NIOF), EGYPT.

Samar Kamel and Heba M. A. Abdelrazek, Physiology Department, Faculty of Veterinary Medicine, Suez Canal University. EGYPT. dietary supplement [2]. Cat fish are economical species used for eating in Ismailia city because of their low prices compared with other fish species.

The basic function of the immune system is to protect an organism against infection in order to minimize the fitness costs of being infected. The available information indicates that fish respond to parasitic infestations by activating different innate and adaptive immune mechanisms. Some innate activities such as inflammatory and cellular reactions, phagocytic activities, complement and humoral factors. Most of which were demonstrated to be involved in the immune response to parasitoses [3]. The need for multi-pronged approaches to identify solutions in control of these parasites is increased. According to life-history theory, energy resources are in a trade-off between the costly demands of immunity and other physiological demands. Concerning fish, both physiology and immunity are influenced by presence of parasites [4]. However, parasites and diseases are the most serious limiting cause in aquaculture production. The most predisposing factor for these diseases is the increased density of cultured aquatic populations in restricted bodies of water. The increased density in aquaculture makes pathogens and parasites transmission from one fish to another easier thus increasing the risk of human exposure.

Therefore, this study was produced to investigate the impact of digenetic trematodes encysted metacercaria (EMC) infestation on leukogram and biochemical parameters of the catfish (Clarias garapienus), which is considered as the most widely distributed fish species in Africa [5] and one of the most popular economic fish in Egypt [6].

\section{MATERIALS AND METHODS}

\section{A. Sampling area}

Samples were collected from Suez Canal region, Ismailia city, Egypt. This area is lying between longitudes $32 \circ 20$ / and $32 \circ 35 / \mathrm{E}$ and between latitudes $29 \circ 55 /$ and $31 \circ 15 / \mathrm{N}$ with an average length of $164 \mathrm{~km}$ along the major axis.

\section{B. Fish sampling}

A total number of 100 C.gariepinus were examined in this study which collected from fish market which captured from Lake EL-Temsah in Ismailia city, Egypt, from July to 
November 2018. The fish specimens were then transported freshly in cold ice box to the laboratory of Fish diseases at National Institute of Oceanography and Fisheries (NIOF), Suez branch, Egypt. Some of fish samples examined freshly wherever the other kept in refrigerator $\left(-4^{\circ} \mathrm{C}\right)$ not more than 7 days to keep metacercarial cysts alive. In the lab total length (TL), mass and sex (S) were recorded. Each fish was dissected into 4 subsamples to facilitate parasitic examination.

\section{Blood samples, spleen and liver mass calculations}

All fish samples markered and blood samples collected from the dorsal vein immediately from each fish by heparinized syringes, blood will preserve in heparinized tubes [7]. Blood samples used for measuring total leukocyte counts (TLC) and liver enzymes Alanine amino-transferase (ALT), Aspartate amino-transferase (AST), Total protein (TP), albumen (ALb) and globulin(GL), the later parameters were considered to be an important parameter of fish health status [8].

\section{D.Parasitic isolation and examination}

The fish samples were dissecting from the ventral side [9]. The body cavity, stomach, intestine, spleen, liver, kidneys, heart, muscles, swim bladder and gonads were separated and examined carefully under a dissecting microscope for the presence of parasites. Parasite fixation and preservation was done according to [10]. Parasite identification was done according to major taxonomic accounts [10\& $11 \& 12 \& 13$ ]. Metacercariae were isolated and recovered using the standard pepsin digestion procedure described by [14], and then calculated the number of excested metacercarial cystes under light electron microscope.

\section{E. Histopathological examinations}

Liver, spleen, kidney and musculature, organs containing digenetic trematodes (EMC) were preserved in formalin $10 \%$ for $24 \mathrm{hr}$ then transferred to $70 \%$ ethyle alcohol for completely preservation. The specimens were dehydrated in ascending grades of ethyl alcohol (70- 80- 95-100\%) for 1-2 hrs., and then cleared in $50 \%$ ethyl alcohol- Xylen mixture followed by two changes of Xylen for $1 \mathrm{hr}$ each until the tissue become transparent. Then the specimens were embedded in paraffin Xylen mixture (1:1) for 30 minutes in scaling hot air oven. Later, the specimens were embedded in pure paraffin wax and left for 0.5-1 hr., to harden. Paraffin sections of about 5 micron were prepared and stained with Haematoxylin and Eosin stain (H\&E) according to [15\& 16].

\section{RESULTS}

A total of 100 random C.gariepinus fish were collected among them, 47 fish were females (47\%) and all of them were found infected with EMC. Out of 53 males (53\%), 39 fish were found infested (39\%). After processing the digestion method for $1 \mathrm{~g}$ musculature tissue infested with EMC, found that the total numbers of cysts was $69 \mathrm{cyst} / \mathrm{g}$.

\section{A. Physical parameters and infested fish statistics:}

The average body mass of collected infested fish, males and females were $313.60 \pm 20.05$ and $346.90 \pm 18.77 \mathrm{~g}$ respectively, while the non-infested males were $272.8 \pm 16.83 \mathrm{~g}$. The average total length in both infested males and females fish were $35.92 \pm 0.88$ and $36.14 \pm 0.68 \mathrm{~cm}$. respectively, while non-infested males were $33.36 \pm 0.87 \mathrm{~cm}$.

The average spleen mass in both males and females infested fish were $0.24 \pm 0.01$ and $0.24 \pm 0.01$ respectively, while noninfested males were $0.2193 \pm 0.01$.

The average liver mass in both males and females infested fish were $2.65 \pm 0.14$ and $2.73 \pm 0.07$ respectively, while noninfested males were $2.017 \pm 0.17$.

\section{B. Total and differential leukocytes count:}

Table (1) showing that non-significant alteration among groups in TLC. Neutrophils percent revealed significant $(P<0.05)$ decrease in both infected males $(\mathrm{M})$ and females $(\mathrm{F})$ than non-infested ones. There was non-significant alteration between infested $\mathrm{M}$ and $\mathrm{F}$. Lymphocytes, Monocytes and Basophils percentage declared non-significant changes among groups. However Eosinophils percentage significantly $(P<0.05)$ increased in infested $\mathrm{M}$ and $\mathrm{F}$ than non-infested ones. There was a non-significant variation between males and females infested fish. 
TABLE I: TOTAL AND DIFFERENTIAL LEUKOCYTE COUNT IN BOTH MALES (M) AND FEMALES (F) C. GARIEPINUS

\begin{tabular}{|c|c|c|c|c|}
\hline & $\begin{array}{c}\text { Infested } \\
(\mathrm{F})\end{array}$ & $\begin{array}{c}\text { Non-infested } \\
(\mathrm{F})\end{array}$ & $\begin{array}{c}\text { Infested } \\
(\mathrm{M})\end{array}$ & $\begin{array}{c}\text { Non-infested } \\
(\mathrm{M})\end{array}$ \\
\hline TLC $(\mu \mathrm{l})$ & $14727 \pm 191^{\mathrm{a}}$ & $7905 \pm 1072^{\mathrm{a}}$ & $27400 \pm 5294^{\mathrm{a}}$ & $23043 \pm 12992^{\mathrm{a}}$ \\
\hline $\begin{array}{c}\text { Neutrophil } \\
\%\end{array}$ & $44.40 \pm 0.93^{\mathrm{a}}$ & $53.20 \pm 1.59^{\mathrm{b}}$ & $43.80 \pm 1.07^{\mathrm{ad}}$ & $53.40 \pm 1.03^{\mathrm{c}}$ \\
\hline $\begin{array}{c}\text { Lymphocyte } \\
\%\end{array}$ & $37.40 \pm 1.29^{\mathrm{a}}$ & $36.00 \pm 1.38^{\mathrm{a}}$ & $38.80 \pm 0.73^{\mathrm{a}}$ & $36.40 \pm 1.12^{\mathrm{a}}$ \\
\hline $\begin{array}{c}\text { Eosinophil } \\
\%\end{array}$ & $11.60 \pm 0.93^{\mathrm{a}}$ & $4.40 \pm 0.24^{\mathrm{b}}$ & $11.60 \pm 1.63^{\mathrm{ad}}$ & $4.20 \pm 0.37^{\mathrm{c}}$ \\
\hline Monocyte \% & $6.40 \pm 0.51^{\mathrm{a}}$ & $6.00 \pm 0.84^{\mathrm{a}}$ & $6.80 \pm 0.37^{\mathrm{a}}$ & $5.40 \pm 0.40^{\mathrm{a}}$ \\
\hline Basophil \% & $0.20 \pm 0.20^{\mathrm{a}}$ & $0.40 \pm 0.24^{\mathrm{a}}$ & $0.20 \pm 0.20^{\mathrm{a}}$ & $0.60 \pm 0.24^{\mathrm{a}}$ \\
\hline
\end{tabular}

a-d means there was statistically significant difference between values at $(P<0.05)$ within the same row.

\section{Biochemical parameters}

Table (2) revealed significant $(P<0.05)$ decrease in TP, $\mathrm{ALb}$, and GL levels in infested males while females showed non-significant alteration. ALb levels showed significant $(P<0.05)$ increase in females infested fish than males. However GL and TP showed non-significant variations between infested males and females.

Both ALT and AST activities were significantly $(P<0.05)$ increased in infested males and females than non-infested ones. No significant difference was observed between infested males and females.

TABLE II: BIOCHEMICAL PARAMETERS IN BOTH MALES (M) AND FEMALES (F) C. GARIEPINUS

\begin{tabular}{|c|c|c|c|c|}
\hline & $\begin{array}{c}\text { Infested } \\
(\mathrm{F})\end{array}$ & $\begin{array}{c}\text { Non- } \\
\text { infested } \\
(\mathrm{F})\end{array}$ & $\begin{array}{c}\text { Infested } \\
(\mathrm{M})\end{array}$ & $\begin{array}{c}\text { Non- } \\
\text { infested } \\
(\mathrm{M})\end{array}$ \\
\hline $\begin{array}{c}\mathrm{GL} \\
(\mathrm{g} / \mathrm{dl})\end{array}$ & $1.80 \pm 0.13^{\mathrm{a}}$ & $2.12 \pm 0.44^{\mathrm{ab}}$ & $1.41 \pm 0.11^{\mathrm{a}}$ & $2.76 \pm 0.32^{\mathrm{b}}$ \\
\hline $\begin{array}{c}\mathrm{ALb} \\
(\mathrm{g} / \mathrm{dl})\end{array}$ & $2.11 \pm 0.12^{\mathrm{a}}$ & $2.66 \pm 0.19^{\mathrm{ab}}$ & $1.85 \pm 0.18^{\mathrm{b}}$ & $2.42 \pm 0.26^{\mathrm{ab}}$ \\
\hline $\begin{array}{c}\mathrm{T} . \mathrm{P} \\
(\mathrm{g} / \mathrm{dl})\end{array}$ & $3.91 \pm 0.21^{\mathrm{a}}$ & $4.78 \pm 0.42^{\mathrm{a}}$ & $3.26 \pm 0.17^{\mathrm{ab}}$ & $5.18 \pm 0.33^{\mathrm{c}}$ \\
\hline $\begin{array}{c}\mathrm{AST} \\
(\mathrm{U} / \mathrm{L})\end{array}$ & $106.80 \pm 13.6^{\mathrm{a}}$ & $72.17 \pm 9.91^{\mathrm{b}}$ & $117.70 \pm 13^{\mathrm{a}}$ & $70.79 \pm 9.1^{\mathrm{b}}$ \\
\hline $\begin{array}{c}\mathrm{ALT} \\
(\mathrm{U} / \mathrm{L})\end{array}$ & $77.90 \pm 7.51^{\mathrm{a}}$ & $40.61 \pm 5.21^{\mathrm{b}}$ & $78.00 \pm 8.75^{\mathrm{a}}$ & $\begin{array}{c}39.21 \pm 4.98 \\
\mathrm{c}\end{array}$ \\
\hline
\end{tabular}

a-c means there was statistically significant difference between values at $(P<0.05)$ within the same row.

\section{D.Parasitological Findings:}

As shown in Figure 1, encysted metacercaria embedded in most of the examined organs such as liver, spleen, kidney and musculatures. The cysts are circular in shape characterized by double outer membrane containing pigmented granules in the inner part. The morphological characterization of the digenetic cyst is similar to the family Heterophyidae..

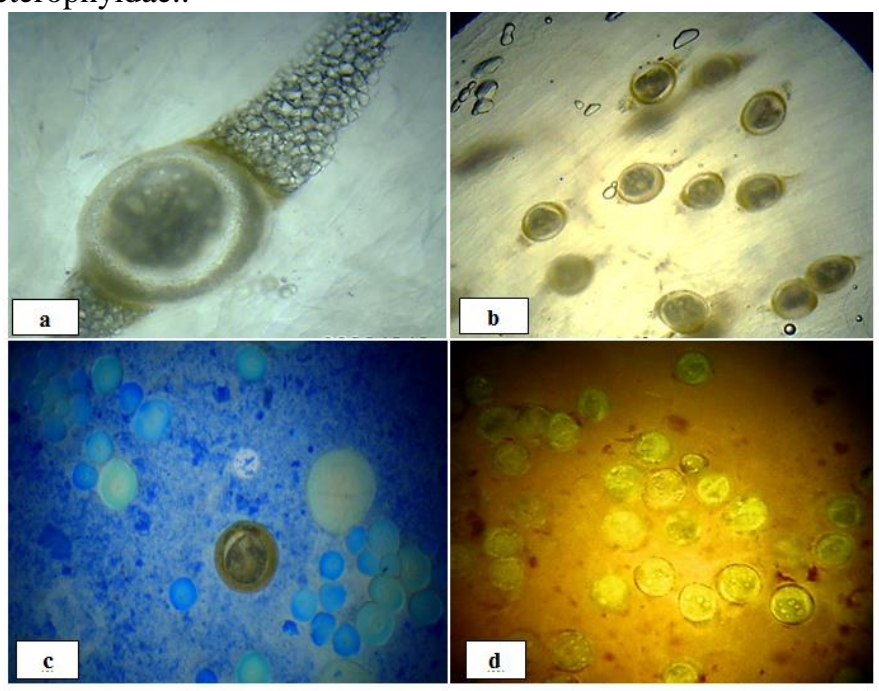

Fig. 1, photographs of EMC (a) presents encysted metacercaria embedded the musculature of C.gariepinus which showing heavy infestations in (b). In (c) encysted metacercaria found inside the ova with free movement. (d) Showing heavy infestations with encysted metacercaria in the liver tissue

\section{E. Histopathological Findings}

The examined fish revealed heavy infested muscles with multiple encysted metacercaria with different sized and shapes (Fig. 2). Each cyst surrounded by thick fibrous tissue capsule. Infested muscles showed severe destruction and hypertrophy of adjacent muscles. Hyaline degeneration and

Inter-muscular edema was also observed (a). Multiple encysted metacercaria cysts were observed also in liver causing atrophy, degeneration and necrotic changes of adjacent hepatocytes (b). Focal, solitary encysted metacercaria cysts were observed in both kidney and spleen causing damage of neighboring tissues (c \& d). 


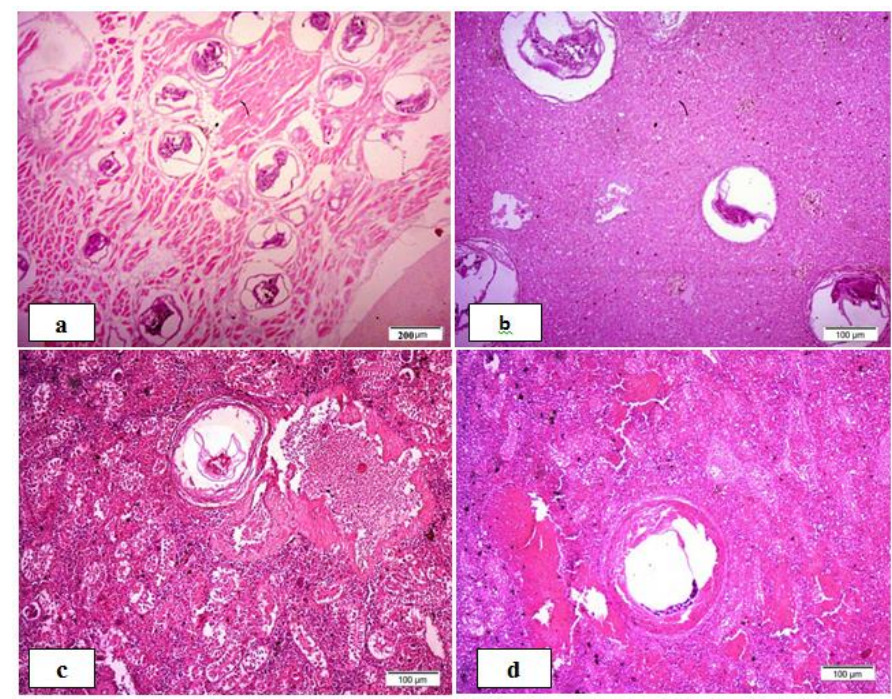

Fig. 2 (a): Muscles of cat fish showing heavy infestation of muscles with encysted metacercaria that causing atrophy and necrosis of neighboring muscles. H\&E, scale bar 200. (b): liver of cat fish showing multiple encysted metacercaria cysts along with atrophy, degeneration and necrosis of adjacent hepatocytes. H\&E, scale bar 100. (c): kidney of cat fish showing large encysted metacercaria cyst causing degeneration and atrophy of adjacent tubules and glomeruli. H\&E, scale bar 100. (d): spleen of cat fish showing large encysted metacercaria cyst with thick fibrous capsule with degeneration and atrophy and necrosis of splenic tissue. H\&E, scale bar 100 .

\section{DISCUSSION}

Fish in ecosystem face a wide range of enemies such as competitors, predators and parasites. Parasites may decrease fish species densities, size composition and affect commercially economically stocks. This mainly depends on the variability of species, habitats and seasonal changes. Because of their complex life cycles, parasites are indicative of many aspects of their hosts' biology, such as host nature, diet, recruitment, migration, population distinctness and even phylogeny, so parasites are a good indicator of environmental pollutants and stress [17].

C.gariepinus fish recorded highly infestations with EMC in several organs as reported in results, this was agreed with [18\& 19\& 20] who reported that the highest prevalence rate of encysted metacercariae was recorded in catfish, which may be due to a lot of Heterophyidae species as zoonotic and have very similar transmission patterns. This parasitic group considered a very significant problem in food safety and quality in aquatic ecosystem. Liver and spleen in infested samples with EMC recorded different mass than normal ones. This is because of the function of both organs in detoxification, immunity, and defense against pathogens; this was described briefly by [21].

Present results revealed non-significant alteration among groups in TLC. However, the neutrophils percent significantly declined in infested than non-infested ones. This observation denoted suppression in first line of defense, neutrophils, against pathogens in innate immune response [22] that caused by EMC infestation. Eosinophils percentage significantly increased in infested $\mathrm{M}$ and $\mathrm{F}$ than non-infested ones. The increment in eosinophils percentage is characteristic for parasitic infestation where these cells produce cytotoxic cationic proteins, like eosinophil peroxidase, major basic protein (MBP), and eosinophil cationic protein. These proteins help the body to overwhelm the parasitic infestation [23]. Both eosinophilia and the increased spleenosomatic mass indicate stimulation of the immune system.

$\mathrm{TP}, \mathrm{ALb}$, and GL levels showed significant decrease in infested males while females showed non-significant alteration. Our results were in harmony with [24\& 25]. They demonstrated that parasitic infestation of tilapia was associated with reduction in blood protein levels. This concurred with the presence of EMC in hepatic tissue that caused serious pathological changes. The liver is main responsible organ for protein biosynthesis [26\& 27]. Parallel to these results, ALT and AST activities were significantly increased in infested males and females than non-infested ones.

[28] recorded that similar elevation in serum liver enzymes ALT and AST activities in case of stress, liver injury or inflammations in C. gariepinus ponds in Nigeria. So due to highly infestations with EMC in the liver tissue, the enzymes level recorded high. This could be attributed to the serious degenerative changes and necrosis induced by EMC in liver tissue that altered hepatic cell membrane permeability and caused leakage of these intra cellular enzymes into the blood [29].

Parasitological findings recorded EMC in all examined organs and found in females higher infestations (47\%) than males (39\%), this wasn't agreed with what stated by Salah, et al, (2005) who found that The infection was higher in males $(71.43 \%$ and $56.62 \%)$ than females $(28.57 \%$ and $43.37 \%)$ in both metacercarial species Prohemistomum vivax, Mesostephanus applendiculatus infested catfish. [30] Reported that several heterophyid species, including Haplorchis species can cause significant pathology often fatal, in the heart, brain and spinal cord of humans so we recommended that next studies should investigate other trematode species infested aquaculture and found effective methods to control snails and migratory birds which considered the main reasons of metacercaria transmission.

Histopathology provides a rapid method to detect the abnormalities and pathogens in different organs and it can be considered as the indicator for abnormal condition for fish environment, Histology and histopathology could be used as bio-indicator tools or indicators of health in toxicity studies as they made early warning signs of disease [31\& $32 \& 33]$ explained that the circulatory and inflammatory reactions that seen in the infested tissue could be due to the effect of toxic metabolites produced by the larvae of EMC. The observed connective tissue capsule represented the tissue reaction of the affected fish by the prolonged irritations of the parasitic cysts. The aggregation of melanomacrophages indicated that the body defense and give explanation to the black spots that observed in the infected fish. The degenerative changes that observed in the affected organs could be due to the pressure or toxic products induced by the parasitic cysts.

As shown in the results there are sever damages in the infested organs as degeneration and necrosis for hepatic cells, 
spleen and renal tubules also showing degenerations in musculature with indication of cysts embedded in the tissue this was like what explained before by [34\& 35\& 36].

\section{CONCLUSION}

The present study evaluated the parasitic infestation in $C$. gariepinus fish with EMC. The infestation wit EMC produced adverse effect on DLC and serum biochemical parameters. As well as histopathological lesions were detected. These effects need further investigations to enable elimination to such parasite.

\section{REFERENCES}

[1] Sabri, D. M.; El-Danasoury, M. A.; Eissa, I. A. and Khouraiba, H. M: Impact of Henneguyosis Infestation on Hematological Parameters of Catfish (Clarias gariepinus). Int. J. Agric. Biol., (2009): 11: 228-230.

[2] WHO, World Health Organization: Food Based Dietary Guidelines in the WHO European Region. EUR/03/5045414. (2003): Available at: http://www.who.org Denmark.

[3] SITJÀ, B, A Fish Immune Response to Myxozoan Parasites, Parasite. (2008): 15, 420-425.

[4] Karolína Rohlenová1, Serge Morand, Pavel Hyršl, Soňa Tolarová, Martin Flajšhans and Andrea Šimková1* Are fish immune systems really affected by parasites? An immunoecological study of common carp (Cyprinus carpio) (2011). Parasites \& Vectors, 4:120.

[5] Skelton, P.,. A Complete Guide to the Fresh Water Fishes of Southern Africa, p: 388. (1993). Southern Book Publishers, Halfway House.

[6] Brewer, D.J. and R.F. Friedman, Fish and Fishing in Ancient Egypt, 1st edition, pp.: 60-63. (1989), Aris and Phillips Ltd., Warminster, Wilshire.

[7] Pravda D, Svobodová Z: Haematology of Fishes (in Czech) Brno: Noviko; (2003).

[8] Jill E. Arnold, M.S, M.T. (ASCP): Hematology of Fish: WBC and RBC Cell Morphology, Proceedings of the ACVP/ASVCP Annual Meetings Monterey, California, USA (2009).

[9] Amlacher, E. Textbook of fish diseases, (Engl.Transl.). T.F.H. Publ., Jersey City, (1970)..

[10] Hoffman, G. L. Parasites of North American freshwater fishes, 2 nd, edn. Cornell Univ. Press, London, (1998).

[11] Bykhovskaya-Pavlovskaya, I. E., A. V. Gusev, M. N. Dubinina, N. A. Izyumova, T. S. Smirnova, I. L. Sokolovskaya, G. A. Shtein, S. S. Shul'man, and V. M. Epshtein, Key to parasites of freshwater fish of the U. S. S. R. Akad. Nauk, S. S. S. R., Moscow, (In Russian) (1962).

[12] Gussev, A. V. Parasitic metazoans: Class Monogenea. In: Bauer, O. N. (Ed.). Key to the parasites of freshwater fish fauna of the U.S.S.R. Nauka, Leningrad 2: 1-424. (In Russian) (1985).

[13] Pugachev, O. N., P. I. Gerasev, A. V. Gussev, R. Ergens, and I. Khotenowsky, Guide to monogenoidea of freshwater fish of Palaeartic and Amur regions, Ledizioni Ledipublishing, Milano(2010)..

[14] Dubey, J.P. Refinement of pepsin digestion method for isolation of Toxoplasma gondii from infected tissues. Vet. Parasitol. 74, 7577(1998). https://doi.org/10.1016/S0304-4017(97)00135-0

[15] Drury, A.A. and Wallington, E.A. Carleton's histological technique. 5th Ed., Oxford Univ(1980).

[16] Bancroft, J.; Steven, A. and Turner, D. Theory and practice of histological techniques 4th Ed. Churchill, Livingstone, London (1996).

[17] Palm HW, Kleinertz S, R€uckert S, Parasite diversity as an indicator of environmental change? An example from tropical grouper (Epinephelus fuscoguttatus) mariculture in Indonesia. Parasitology. (Suppl.) doi:10.1017/50031182011000011, (2011)

[18] Eissa, I.A.M., M.A. Mona, M.E. Hala and S.M. Aly, Yellow grub disease among Oreochromis niloticus in relation to food quality and pathological alterations. SCVMJ, IV (2): 179-194, (2001).

[19] Abou-Eisha, A.M., R.E. Saleh, H.M. Fadel, E.M. Youssef and Y.A. Helmy,. Role of fresh water fishes in the epidemiology of some zoonotic trematodes in Ismailia province. SCVMJ, XIII (2): 653-676, (vet.scuegypt.edu.) (2008).
[20] Amina Ibrahim El-Sayed El-Mansy,: Effect of Processing Steps and Aqueous Extracts of Some Medicinal Plants on Controlling Fish Parasites in Egypt, Acta Parasitologica Globalis 7 (2): 27-53. (2016).

[21] Camila F. Sales1 , Regianne F. Silva1 , Marília G. C. Amaral1 , Fabrício F. T. Domingos2 , Rosy I. M. A. Ribeiro3, Ralph G. Thomé1 and Hélio B. Santos,: Comparative histology in the liver and spleen of three species of freshwater teleost. Neotropical Ichthyology, 15(1): e160041. DOI: 10.1590/1982-0224-20160041. Published online: 30 March 2017 (ISSN 1982-0224) Printed: 31 March 2017 (ISSN 16796225). (2017)

[22] Mortaz, E. Alipoor S. D, Adcock I. M, Mumby M, and Koenderman L. Update on Neutrophil Function in Severe Inflammation Front Immunol.; 9: 2171.Published online 2018, Oct 2. Doi: 10.3389/fimmu.2018.02171.( 2018).

[23] Kita, H., \& Gleich, G. J. Eosinophils and Ig E receptors: a continuing controversy. The Journal of The American Society of Hematology VOL 89, NO 10.(1997).

[24] Vonzi, N. E; Savich, M. V, and Ivasik, V. M. Immuno-physiological reactivity of carp and hybrids parasitic infections. Izdatel Stvo (NaukDumaka):pp.93-94. (1979)

[25] El-Seify, M A; Soliman, M. K. and Mahfouz, N. B. Effect of parasitism on certain immunological parameters of c Melo, J. F. B., Lundstedt, L. M., Inoue, L. A. K., Metón, I. (1998).

[26] Sáez, L., Zuvić, T., Amthauer, R., Rodríguez, E., \& Krauskopf, M. Fish liver protein synthesis during cold acclimatization: seasonal changes of the ultrastructure of the carp hepatocyte. Journal of Experimental Zoology, 230(2), 175-186. (1984).

[27] Baanante, I. V., \& Moraes, G. Glycolysis and gluconeogenesis in the liver of catfish fed with different concentrations of proteins, lipids and carbohydrates. Arquivo Brasileiro de Medicina Veterinária e Zootecnia, 68(5), 1251-1258. ultured fishes. Egypt j. Aqut. Boil. \& Fish, 2, 4:379405. (2016).

[28] Dorcas I.K. And Solomon R.J. Calculation Of Liver Function Test In Clarias Gariepinus Collected From Three Commercial Fish Ponds. Nature and Science;12 (10) 107-123. (ISSN: 1545-0740). (2014).

[29] Harper, C: Wernicke's encephalopathy: a more common disease than realized. A neuropath logical study of 51 cases. J Neurol Neurosurg Psychiatry 42(3):226-231. (1979).

[30] WHO, Control of food-borne trematode infections. WHO Tech. Rep. Ser. No., 849: 1-157. (1995).

[31] Zakia A.M., Faten F. Mohammed and Abdel-Rahman A. Ecomonitoring of Climate Impact on Tilapia niloticus Performance and Development of Different Histopathological Changes, Global Veterinaria 8 (3): 209-221. (2012).

[32] Shareef, P. A. A and Abidi S. M. A. Studies on the epidemiology and histopathology of Euclinostomum heterostomum (Trematoda; Digenea) infection in Channa punctata from North India Arch. Pol. Fish. 23: 133140 DOI 10.1515/aopf-2015-0015. (2015)

[33] Salah Aly, Ismail Eissa, Ahmed Badran, M. Elamie, B. Hussain.: Pathological Studies on Encysted Metacercariae Infections among some Freshwater Fish in Egyptian Aquaculture. Duetscher Tropentag, October 11-13, 2005; Hohenham Univ., Stuttgart, Germany. (2005).

[34] Altinok I., Capkin E- Histopathology of rainbow trout exposed to sub lethal concentrations of methiocarb or endosulfan - Toxicol. Pathol. 35: 405-410. (2007).

[35] Butchiram M.S., Tilak K.S., Raju P.W. - Studies on histopathological changes in the gill, liver and kidney of Channa punctatus (Bloch) exposed to Alachlor - J. Environ. Biol. 30: 303-306. (2009).

[36] Kelly J.M., Janz D.M. - Assessment of oxidative stress and histopathology in juvenile northern pike (Esox lucius) inhabiting lakes downstream of a uranium mill - Aquat. Toxicol. 92: 240-249. (2009).

[37] Mohamed F.A.S. - Histopathological Studies on Tilapia zillii and Solea vulgarisfrom Lake Qarun, Egypt - World. J. Fish. Mar. Sci. 1: 29-39. (2009). 